\title{
Antimicrobial Resistance and Virulence Factors of Campylobacter coli Isolated from Chicken in Côte d'Ivoire
}

\author{
Goualié Gblossi Bernadette $^{1^{*}}$, Bakayoko Souleymane ${ }^{2}$ \\ and Konan Marie-Pierre Laure ${ }^{1}$ \\ ${ }^{1}$ Laboratory of Biotechnology, Faculty of Biosciences, Felix Houphouet-Boigny University, \\ Abidjan, 22 BP 582, Abidjan, Côte d'Ivoire. \\ ${ }^{2}$ Laboratory of Bacteriology, Treichville University and Hospital Center, Abidjan, Côte d'Ivoire.
}

Authors' contributions

This work was carried out in collaboration among all authors. Authors GGB and KMPL designed the study, wrote the protocol, wrote the first draft of the manuscript and managed the analyses of the study. Author BS managed the literature searches. All authors read and approved the final manuscript.

Article Information

DOI: 10.9734/ARRB/2020/v35i1130302 Editor(s):

(1) Dr. Paola Angelini, University of Perugia, Italy. Reviewers:

(1) Ali Salah Hasan, University of Babylon, Iraq. (2) Leandro dos Santos Machado, Universidade Federal Fluminense (UFF), Brazil. Complete Peer review History: http://www.sdiarticle4.com/review-history/63135

Original Research Article

Received 09 September 2020

Accepted 13 November 2020

Published 20 November 2020

ABSTRACT

Aims: Campylobacters species are major causes of gastroenteritis in human. The main risk factor of infection is consumption of contaminated or by cross-contaminated poultry meat. The aims of this study were to analyze antimicrobial profile and virulence factors associated to Campylobacter coli isolated from chicken's ceaca in commercial slaughter in Abidjan.

Methodology: A total of 336 chicken ceaca samples were collected from market of two municipality of Abidjan and were examined by conventional microbiological methods and molecular test using PCR. The antibiotic susceptibility tests of the isolates were determined by disk diffusion method the presence of virulence genes was examined using simple PCR method.

Results: From these samples, $210 / 336$ (62.50\%) were positives for Campylobacter. Among the isolates, 53 strains confirmed as $\mathrm{C}$. coli by using PCR detection were used for phenotypic and genotypic analysis. Of these strains, $51 / 53$ were positive for one or more antibiotics molecules 
tested. The highest rate of antimicrobial resistance was found for nalidixic acid 51/53 (96.22\%), tetracyclin 49/53 (92.45\%) and ciprofloxacin 38/53 (71.69\%). Moreover, MDR including 3, 4, 5 and 6 antibiotics families was detected in $11 / 53(20.75 \%)$ of isolates. On the other hand, detection of virulence gene shows presence of cadF gene in $86.01 \%$ of isolates while $82.21 \%$ were positive for the three $c d t(A, B$ and $C)$ genes.

Conclusion: We reported in this study the presence of high pathogenic Campylobacter coli contamination of the studied chickens. Molecular identification of the bacteria was performed and determination of high resistance to antimicrobials of the fluoroquinolone family was revealed.

Keywords: Campylobacter coli; antibiotics; virulence factors; Côte d'lvoire.

\section{INTRODUCTION}

Campylobacter species are Gram-negative, micro-aerophilic bacteria, which are a major cause of bacterial gastroenteritis in humans. Generally, within the genus Campylobacter, C. jejuni and $\mathrm{C}$. coli are considered to be the most common causes of bacterial gastroenteritis both in developed and developing countries $[1,2]$.

In the United States for example, campylobacteriosis was the third most important bacterial foodborne disease, with an incidence of laboratory-confirmed cases above 13.5 cases per 100,000 populations in 2014 . In developing countries, Campylobacter has been associated to 11.3 to $21 \%$ of diarrhea episodes in children under the age of two years [3]. In generally, $\mathrm{C}$. coli account a further $5-10 \%$ of cases of all gastroenteritis due to Campylobacter.

Because of the high rate of Campylobacter jejuni isolated in human infection cases, little attention is paid to C. coli. Indeed, consumption of chicken meat is considered the main risk factor for $\mathrm{C}$. jejuni infections in many countries [4] while $C$. coli contamination sources are stayed litle know. Although pigs are believed to be the main reservoir of $\mathrm{C}$. coli, presence of this bacterium has also been reported in chickens. In this condition, chicken also could be a source of $\mathrm{C}$. coli contamination for the consumer $[5,6,7]$. As in C. jejuni strains, C. coli pathogenicity is due to various factors including cytotoxin production, intestinal cell invasion, extraintestinal adherence and translocation $[8,9,10,11,12]$.

In most cases, antibiotic (erythromycin, ciprofloxacin, tetracycline, etc.) treatment is necessary to treat Campylobacter infection, but Campylobacter spp. Have recently begun to Show resistance several drugs. In a previous study, Campylobacter jejuni isolates from poultry samples in Côte d'Ivoire were examined for antibiotic resistance $94.64 \%$ of isolates were resistant to one or more antimicrobial agents including tetracycline, erythromycin, ciprofloxacin, nalidixic acid [13]. Generally, the overuse of these molecules in poultry production systems promotes the development of resistant and even multidrug-resistant bacteria [14]. In Côte d'Ivoire, antibiotics are widely used to prevent, control, and treat bacterial infections as well as growth promoters during poultry production [15]. Thus, the aim of this study is to analyze antimicrobial profile and virulence factors associated to Campylobacter coli isolated from chicken's ceaca in commercial slaughter in Abidjan.

\section{MATERIALS AND METHODS}

\subsection{Samples Collection}

This study was conducted in two municipalites of Abidjan including Abobo and Adjamé. Samples were collected at the largest market poultry slaughter sites of each area. A total of 336 samples of chicken ceaca were collected and were analyzed for Campylobacter isolation.

\subsection{Isolation and Identification of $C$. coli Strains}

Isolation of Campylobacter sp. was performed with passive filtration method as previously described by Goualié et al. [13]. Thus, approximately $1 \mathrm{~g}$ of ceaca contents was transferred in $9 \mathrm{~mL}$ of Preston enrichment broth base (OXOID LTD., Basingstoke, Hampshire, UK) supplemented with of $5 \%(\mathrm{v} / \mathrm{v})$ fresh sheep blood. Each sample was incubated during 24 hours at $37 \circ \mathrm{C}$ under microaerobic conditions. After incubation, a part of the broth was filtered through acetate cellulose filter $(0.45 \mu \mathrm{m})$ on Columbia agar (Sharlau; Barcelona, Spain) supplemented with $5 \%(\mathrm{v} / \mathrm{v})$ fresh sheep blood at and plate were incubated at $37{ }^{\circ} \mathrm{C}$ during 2 days under microaerobic conditions. After incubation, five presumptive colonies from each 
agar plate were identified as Campylobacter by using morphological, cultural and biochemical methods [16]. The molecular identification was consisted of PCR amplification of the ask gene encoding to $C$. coli aspartokinase. Sequences of primers used for gene amplification are CC18F 5' GGTATGATTTCTACAAAGCGAG 3' and CC519R 5' ATAAAAGACTATCGTCGCGTG 3' [17]. PCR was performed in final volume of $50 \mu \mathrm{L}$ mix containing $0.6 \mu \mathrm{L}$ of each dNTP $(10 \mathrm{mM}), 3$ $\mu \mathrm{L}$ of $\mathrm{MgCl}_{2}(25 \mathrm{mM}), 10 \mu \mathrm{L}$ of Bu$\square$ er $5 \mathrm{X}$ DNA Taq polymerase, $0.2 \mu \mathrm{L}$ of Taq polymerase (Promega, WI USA) $1.4 \mu \mathrm{L}$ of each primer (100 $\mu \mathrm{M})$. Amplification reactions were carried out using thermal cycler (Gene Amp PCR system type 9700, Applied Biosystems, Villebon-suryvette, France). The program was as follows: pre-denaturation at $95{ }^{\circ} \mathrm{C}$ for $15 \mathrm{~min}, 25$ cycles of denaturation at $95{ }^{\circ} \mathrm{C}$ for $0.5 \mathrm{~min}$, annealing at $58{ }^{\circ} \mathrm{C}$ for $1.5 \mathrm{~min}$, and extension at $72{ }^{\circ} \mathrm{C}$ for 1 min. A final extension step at $72{ }^{\circ} \mathrm{C}$ for 5 min was performed. The PCR products were stained with a $0.3 \%$ solution of SIBR Safe green and were visualized under UV light after gel electrophoresis on $1.5 \%$ agarose. Each colony corresponding to Campylobacter coli was stored in $25 \%$ glycerol at $-70^{\circ} \mathrm{C}$ until needed.

\subsection{Antimicrobial Susceptibility}

The $C$. coli susceptibility to the antibiotics was tested by using the disk diffusion method and the following antimicrobial disks (BioRad,) were included: tetracyclin $(30 \mu \mathrm{g})$, erythromycin (15 $\mu \mathrm{g})$, chloramphenicol $(30 \mu \mathrm{g})$, ciprofloxacin (5 $\mu \mathrm{g})$, azithromicin $(15 \mu \mathrm{g})$, gentamicin $(10 \mu \mathrm{g})$ and nalidixic acid $(30 \mu \mathrm{g})$; amoxicillin $(20 \mu \mathrm{g})$. Susceptibility testing to all antimicrobial agents was carried out on Mueller-Hinton agar supplemented with sheep blood that were spread with a 0.5 McFarland standard suspension of each strain in trypton saline buffered (Biorad, France) and incubated for $48 \mathrm{~h}$ at $37^{\circ} \mathrm{C}$ under microaerobic conditions. Zones of inhibition were measured and the isolates were classified as sensitive or resistant according to the CASFM/EUCAST [18] guidelines. Escherichia coli ATCC 25922 and Staphylococcus aureus ATCC 25923 were used as reference strains.

\subsection{Potential Virulence Factors Genes}

To detect the presence of $c d t$ genes ( $c d t A, c d t B$, and $c d t C$ ) and cadF from isolates, the target sequence DNA was amplified by using the bacterium suspension and using the primers listed in Table $1[10,11]$. The PCR products were visualized by gel electrophoresis and UVtransillumination.

\section{RESULTS AND DISCUSSION}

\subsection{Prevalence}

Campylobacters are regarded as important food borne pathogens. In this study, a total of 336 ceaca of chicken were analyzed. Among them, $210 / 336(62.50 \%)$ were positive for Campylobacter. Campylobacter spp. prevalence $(62.50 \%) \%)$ in our study is much lower than those found in Algeria (98\%) [19], Spain (88\%), Portugal (82\%), and Malta (96.3\%) [20] and Morocco (71\%) [21]. Nevertheless, prevalence identified present study is higher than the prevalence reported in Sweden (13.2\%), Finland (3.9\%), and Denmark (19\%) [20, 21]. However, this finding is lower than previous prevalence (above $70 \%$ ) in chicken ceaca reported by Goualié et al. [12] in same area.

Table 1. Primers sequences used in this study and PCR conditions

\begin{tabular}{|c|c|c|c|}
\hline $\begin{array}{l}\text { Target } \\
\text { genes }\end{array}$ & Sequence $\left(5^{\prime} \rightarrow 3^{\prime}\right)$ & PCR Conditions & Size (bp) \\
\hline cadF & $\begin{array}{l}\text { F: TTGAAGGTAATTTAGATATG } \\
\text { R: CTAATACCTAAAGTTGAAAC }\end{array}$ & $\begin{array}{l}94^{\circ} \mathrm{C} / 1 \mathrm{~min} \\
49^{\circ} \mathrm{C} / 1 \mathrm{~min} \\
72^{\circ} \mathrm{C} / 1 \mathrm{~min}\end{array}$ & $400 \mathrm{bp}$ \\
\hline$c d t A$ & $\begin{array}{l}\text { F: GGAAATTGGATTTGGGGCTATACT } \\
\text { R: ATCACAAGGATAATGGACAAT }\end{array}$ & $94^{\circ} \mathrm{C} / 2 \min$ & $165 \mathrm{bp}$ \\
\hline$c d t B$ & $\begin{array}{l}\text { F: GTTAAAATCCCCTGCTATCAACCA } \\
\text { R: GTTGGCACTTGGAATTTGCAAGGC }\end{array}$ & $\begin{array}{l}42^{\circ} \mathrm{C} / 2 \min \\
72^{\circ} \mathrm{C} / 2 \min \end{array}$ & $495 \mathrm{bp}$ \\
\hline$c d t C$ & $\begin{array}{l}\text { F: TGGATGATAGCAGGGGATTTTAAC } \\
\text { R: TTGCACATAACCAAAAGGAAG }\end{array}$ & & $555 \mathrm{bp}$ \\
\hline
\end{tabular}


Difference in prevalence in the both study conducted in the same area could most due to the Campylobacter strains isolation conditions than improvement of farm bioscecurity level. Indeed, in the present study, microaerobic atmosphere was obtained by burning candle in candle jar while in previous study Goualie et al. [12] used gas generating pack. In fact, microaerophilic atmosphere refers to the presence of around $2-10 \%$ of oxygen which can be created manually (e.g., candle jar) or using chemical substances (e.g., gas generating packs) or by the automated systems (e.g., Anoxomat) [22].

But using of burning candle creates an atmosphere with high rate of oxygen (8-11\%) than using of Gas Park (about $3 \%$ ). This high level of oxygen in the jar probably inhibited the growth of some strains of Campylobacter because of stressed in aerobic condition.

On the other hand, the low prevalence observed in some studies is due to improvement of bioscecurity level in most poultry farms. Indeed, in European countries, implementation of bioscecurity strategies allowed with successfully to control Campylobacter and have consequently achieved a lower prevalence of this bacterium in broiler flocks [12]. A total of 53 strains were confirmed as C. coli by using PCR with ask primers. Campylobacter coli are one of the most common bacteria in bacterial gastroenteritis and acute enterocolitis in humans. However, relatively little is known regarding the characteristics of this species in poultry. C. coli as C. jejuni can induce human campylobacteriosis. Thus, because of poor hygiene conditions both in slaughter and during cooking in Abidjan, presence of these bacteria in poultry intestine could induce public health problem.

\subsection{Antimicrobial Profile}

Among 53 tested isolates, 51 strains (96.22\%) were resistant to one or more antimicrobial agents. The highest rate of antimicrobial resistance was observed for nalidixic acid $(96.22 \%)$, tetracyclin $(92.45 \%)$ and Ciprofloxacin (71.69 \%). Comparatively, resistance levels observed to the other antibiotics were relatively low with $35.84 \%$; $26.41 \%$ and $15.09 \%$ and for erythromicin, azithromicin and amoxicillin respectively (Table 2 ). The lowest resistance was observed for gentamycin (3.77\%). The multiple drugs resistance (MDR) was detected in $20.75 \%$ of the tested strains. Among these strains, MDR including three antibiotics families was detected $5 / 53(9.43 \%)$ of these strains while 4/53 (7.54 $\%$ ) of them were resistant to four drugs families, $1 / 53(1.88 \%)$ was resistant to five antibiotics families and $1 / 53(1.88 \%)$ was resistant to six drugs families.

Antibiogram test indicated higher resistance of the microorganisms to ciprofloxacin and nalidixic acid and tetracycline. These high resistances obtained in our study are comparable to those observed in many countries [9, 23-27]. On the other hand, low resistance has been also observed with gentamicin by Rivera et al. [27], in strains isolated in Chile and by Vinueza-Burgos et al. [9] in Ecuador. Antibiotic resistance of Campylobacter spp. is a persistent issue in both veterinary and human medicine because of the indiscriminate use of antibiotics in therapy or as growth promoters. Alfredson and Korolik [28] suggested that the use of enrofloxacin (derivates close to the fluoroquinolones used in human medicine) for example in animals flocks has probably exerted a selection pressure in animal reservoirs. The high percentages of resistance to most antimicrobial agents tested in our study may be due to high usage of these agents as growth promoters or in animal treatment. In fact, in Cote d'lvoire, as in most of developing countries [29], the use of antibiotics for humans and animals is relatively unrestricted. Furthermore, no measures of hygiene are observed in both farms and in the process of slaughter which could cause contamination of poultry carcasses by Campylobacter coli with

Table 2. Distribution of simple resistance in tested strains

\begin{tabular}{lll}
\hline Antibiotics & Number of tested strains & Number (\%) of resistant strains \\
\hline Ciprofloxacin & & $38(71.69)$ \\
Nalidixic acid & & $51(96.22)$ \\
Tetracyclin & $49(92.45)$ \\
Erythromycin & 53 & $9(26.41)$ \\
Azithromycin & & $14(35.84)$ \\
Amoxicillin & & $8(15.09)$ \\
Gentamicin & $2(3.77)$ \\
\hline
\end{tabular}


high antibiotics resistance capacity. Therefore, surveillance of resistance pattern is necessary to guide rational use of antimicrobial agents in poultry farms.

\subsection{C. coli Virulence Factors}

Analysis of C. coli strains for detection of virulence factor indicated that among these 53 isolates, $86.01 \%$ were positive for cadF gene while $82.21 \%$ were positive for the three cdt (A, B and $\mathrm{C}$ ) genes. The high prevalence of cadF gene is similar to those reported by Rozynek et al [23] in C. coli from human and from chicken and by Anja et al. [30] in C. coli from human. These results suggested that cadF gene is probably conserved among Campylobacter spp isolates regardless of their origin [31]. According to authors, the high presence of cadF gene in Campylobacter strains could be due to the key role of this protein in pathogenicity activity of these bacteria. Indeed, CadF is the major determinant implicate in the ability of Campylobacter to bind to host epithelial cells. Moreover, this ability is the first step of pathogenicity and invasion of host cells. The cadF gene encodes, indeed, for a protein that interacts with the host's fibronectin matrix, which is necessary for colonization of the cell surface. On the other hand, it was suggested that cadF protein is allowed to the poultry digestive tract colonization that could explained high prevalence of this gene in Campylobacter strains.

Campylobacter can produce cdt, composed of $\mathrm{A}$, $B$ and $C$ subunits, which are encorded by $c d t A$, $B$ and $C$ genes. In this study, $82.21 \%$ of $C$. coli isolates had these three genes. Lee et al. [32] showed that $71.1 \%$ of Campylobacter isolates for chicken and duck cacass had the three cdt genes. The high rate of cdt genes observed in this study is also agreed with those reported by Bang et al., [11] and Datta et al., [33]. Our results indicate that most of $\mathrm{C}$. coli isolates from poultry ceaca have the potential to produce CDT because of presence of the three genes subunits encoded to the three subunits of this protein.

\section{CONCLUSION}

We reported in this study the presence of high pathogenic Campylobacter coli contamination of the studied chickens. Molecular identification of the bacteria was performed and determination of high resistance to antimicrobials of the fluoroquinolones and tetracyclin families was revealed. Because of importance of $C$. coli in infection cases due to Campylobacter genus, it is crucial to investigate a thorough and reliable monitoring program to reduce the availability of contaminated chicken's products in our country.

\section{ACKNOWLEDGEMENTS}

The authors thank the poultry slaughterers of visited slaughterhouses of visited Abidjan for their kindly collaboration.

\section{COMPETING INTERESTS}

Authors have declared that no competing interests exist.

\section{REFERENCES}

1. Abu-Madi M, Behnke JM, Sharma A, Bearden R, Al-Banna N. Prevalence of virulence/stress genes in Campylobacter jejuni from chicken meat sold in qatari retail outlets. Plos One. 2016;11: e0156938.

2. $\mathrm{Li} J$, Gulbronson $\mathrm{CJ}$, Bogacz $\mathrm{M}$, Hendrixson DR, Thompson SA. FliW controls growth-phase expression of Campylobacter jejuni flagellar and nonflagellar proteins via the posttranscriptional regulator CsrA. Microbiol. 2018;164:1308-1319.

3. Platts-Mills JA, Kosek M. Update on the burden of Campylobacter in developing countries. Curr Opin Infect Dis. 2014; 27:444-450.

4. Young KT, Davis LM, Dirita VJ. Campylobacter jejuni: molecular biology and pathogenesis. Nat Rev Microbiol. 2007;5:665-679.

5. Bacon DJ, Alm RA, Burr DH, Hu L, Kopecko DJ, Ewing CP. Involvement of a plasmid in virulence of Campylobacter jejuni 81-176. Infect Immunol. 2000;68: 4384-4390.

6. Goualié GB, Akpa EE, Kakou-N'Gazoa ES, Guessennd N, Bakayoko S, Niamké LS, Dosso M. Prevalence and antimicrobial resistance of thermophilic Campylobacter isolated from chicken in Côte d'Ivoire. Int J Microbiol. 2012;5.

7. Goualié BG, Ouattara HG, Akpa EE, Guessennd N, Bakayoko S, Niamké S, and Dosso M. Occurrence of multidrug resistance in Campylobacter from Ivorian poultry and analysis of bacterial response to acid shock. Food Sci. Biotechnol. 2014; 23:1185-1191. 
8. Johannessen GS, Garofolo G, Di Serafino G, Kolácková I, Karpíšková R, Wieczorek K, Osek J, Christensen J, Torp M, Hoorfar J. Campylobacter in chicken-Critical parameters for international, multicentre evaluation of air sampling and detection methods. Food Microbiol. 2020;90:10455. [CrossRef][PubMed]

9. Vinueza-Burgos C, Wautier M, Martiny D, Cisneros M, Van Damme I, De Zutter L. Prevalence, antimicrobial resistance and genetic diversity of Campylobacter coli and Campylobacter jejuni in Ecuadorian broilers at slaughter age. Poult Sci. 2017; 96:2366-2374.

10. Konkel ME, Gray SA, Kim BJ, Garvis SG, Yoon J. Identification of the enteropathogens Campylobacter jejuni and Campylobacter coli based on the cadF virulence gene and its product. J Clin Microbiol. 1999;37:510-517.

11. Bang DD, Scheutz F, Gradel KO, Nielsen EM, Pedersen K, Enberg J, Gerner-Smidt P, Handberg K, Madsen M. Detection of seven virulence and toxin genes of Campylobacter jejuni and Campylobacter coli isolates from different sources and cytolethal distending toxin production suggest potential diversity of pathogenic properties among isolates. Genome Lett. 2003;2:62-72.

12. Cover TL, Perez-Perez GI, Blaser MJ. Evaluation of cytotoxic activity in fecal filtrates from patients with Campylobacter jejuni or Campylobacter coli enteritis. FEMS Microbiol Lett. 1990;58:301-304.

13. Goualie GB, Akpa EE, Kakou-N'Gazoa SE, Ouattara HG, Niamke SL, Dosso M. Antimicrobial resistance and virulence associated genes in Campylobacter jejuni isolated from chicken in Côte d'Ivoire. J Infect Dev Ctries. 2019;13(8):671-677.

DOI: $10.3855 /$ jidc. 11355 .

14. Reardon S. Antibiotic resistance sweeping developing world. Nature. 2014;509:141142.

15. Goualie GB, Konan LMP, Karou TAG, Niamke LS. Evolution de la résistance aux antibiotiques de Campylobacter sp. isolés de poulets de chair à Abidjan, Côte d'Ivoire. J. Appl. Biosci. 2020;148:1520215208.

16. Bolton FJ, Wareing DR, Skirrow MB, Hutchinson DN. Identification and biotyping of Campylobacter. in Identification Methods in Applied and Environmental Microbiology, G. R. Board, D. Jones, and
F. A. Skinner, Eds. Blackwell Scientific Publications, Oxford, UK. 1992;151-161.

17. Linton, D.; Owen, R.J.; Stanley, J. Rapid identification by PCR of the genus Campylobacter and five Campylobacter species enteropathogenic for man and animals. Res. Microbiol. 1996;147: 707718. [CrossRef]

18. CASFM/EUCAST. Recommandations du CASFM / EUCAST v.1.0. Comité de l' Antibiogramme de la Société Française de Microbiologie (SFM) EUropean Committee on Antimicrobial Susceptibility Testing (EUCAST) ; 2018.

Available:https://www.sfmmicrobiologie.or g/2019/01/07/casfmeucast-2019/

19. Messad S, Hamdi TM, Bouhamed R, Ramdani BN. Isolement et Fréquence D'antibiorésistance des Campylobacter Thermotolérants Chez le Poulet de Chair Dans la Région D'Alger. Thèse., Ecole Nationale Vétérinaire, 2012;Alger. :2.

20. European Food Safety Agency. Analysis of the baseline survey on the prevalence of Campylobacter in broiler batches and of Campylobacter and Salmonella on broiler carcasses in the EU, 2008. Part A: Campylobacter and Salmonella prevalence estimates. EFSA J. 2010;8(3):1503-1513.

21. Asmai R, Karraouan B, Es-Soucratti K, EnNassiri $H$, Bouchrif $B$, Karib $H$, Triqui $R$. Prevalence and antibiotic resistance of Campylobacter coli isolated from broiler farms in the Marrakesh Safi region, Morocco, Veterinary World, 2020;13(9):1892-1897.

22. Salim SM, Mandal J, Parija SC. Isolation of Campylobacter from human stool samples. Indian J. Med. Microbiol. 2014; 32:35-38.

23. Rozynek E, Dzierzanowska-Fangrat K, SzczezepaÅ B, Wardak S, Szych J, Konieczny $\mathrm{P}$, Albrecht $\mathrm{P}$, Dzierzanowska D. Trends in antimicrobial susceptibility of Campylobacter isolates in Poland (20002007). Pol J Microbiol. 2007;58:111-115.

24. Ferro ID, Benetti TM, Oliveira TCRM, Abrah ao WM, Farah SMSS, Luciano FB, Macedo REF. Evaluation of antimicrobial resistance of Campylobacter spp. isolated from broiler carcasses. $\mathrm{Br}$ Poult Sci. 2015;56:66-71.

25. European Food Safety Authority (EFSA). The European Union summary report on trends and sources of zoonoses, zoonotic agents and food-borne outbreaks in 2012. EFSA J. 2015;12:3547. 
26. Rahimi E, Momtaz $H$, Ameri $M$, Ghasemian-Safaei $H$, Alikasemi M. Prevalence and antimicrobial resistance of Campylobacter species isolated from chicken carcasses during processing in Iran. Poult Sci. 2010;89:1015-1020.

27. Rivera $\mathrm{FN}$, Bustos $\mathrm{R}$, Montenegro $\mathrm{SH}$, Sandoval M, Castillo N, Fern'andez J, Maturana R, Delgado R, Contreras S, Chavez ND, Chavez N, Quevedo L. Genotyping and antibacterial resistance of Campylobacter spp strains isolated in children and in free range poultry. Rev Chil infectologia. 2011;28:555-562. [Article in Spanish].

28. Alfredson DA, Korolik V. Antibiotic resistance and resistance mechanisms in Campylobacter jejuni and Campylobacter coli. FEMS Microbiol Letters. 2007; 277(2):123-132.

29. Goualie GB, Bakayoko S, Coulibaly KJ. Practices of biosecurity measures and their consequences on poultry farms in Abidjan district. Food and Environment Safety. 2020;19(1):33-39.

30. Anja K, Pogačar MŠ, Raspor P, Abram M, Možina SS, Vučković D. Virulence genes and cytokine profile in systemic murine Campylobacter coli infection. Virulence. 2015;6(6):581-590.

DOI: $10.1080 / 21505594.2015 .1042642$

31. Khoshbakht R, Tabatabaei M, Hosseinzadeh S, Shekarforoush SS, Aski $\mathrm{SH}$. Distribution of nine virulenceassociated genes in Campylobacter jejuni and C. coli isolated from broiler feces in Shiraz, southern Iran. Foodborne Pathog Dis. 2013;10(9):764-70.

PMID:23789768;

Available:http://dx.doi.org/10.1089/fpd.201 3.1489

32. Lee J, Jeong J, Lee H, Ha J, Kim S, Choi Y, Lee S. Antibiotic Susceptibility, Genetic Diversity, and the Presence of Toxin Producing Genes in Campylobacter Isolates from Poultry. Int. J. Environ. Res. Public Health. 2017;14(11):1400.

DOI:10.3390/ijerph14111400

33. Datta S, Niwa H, Itoh K. Prevalence of 11 pathogenic genes of Campylobacter jejuni by PCR in strains isolated from humans, poultry meat and broiler and bovine faeces. J Med Microbiol. 2003;53:345348.

(c) 2020 Bernadette et al.; This is an Open Access article distributed under the terms of the Creative Commons Attribution License (http://creativecommons.org/licenses/by/4.0), which permits unrestricted use, distribution, and reproduction in any medium, provided the original work is properly cited.

Peer-review history:

The peer review history for this paper can be accessed here: http://www.sdiarticle4.com/review-history/63135 